\title{
Introduction: In Search of Lost Time?
}

\author{
"Le veritable voyage de découverte ne consiste pas à chercher \\ de nouveaux paysages, mais à avoir de nouveaux yeux." \\ Marcel Proust, À la recherche du temps perdu, vol. 5: La Prisonnière
}

\begin{abstract}
A $t$ the very beginning, it would be probably expedient to be reminded of two simple facts, namely, that European printing with movable type was invented and introduced in the 1440s, while the first Ottoman printing house to print books for the Muslim and Turkish-speaking reading public was established in Istanbul only in the 1720s. That is, Ottoman Turkish printing (and also Muslim, in terms of cultural affiliation) was introduced nearly 300 years later. What was the reason for this considerably late introduction? Although numerous explanations have so far been suggested, the subject remains an enigma whose hidden logic is still to be disclosed. As Marcel Proust's words suggest, sometimes it is better not to seek new horizons of knowledge but to take a look at the existing one through the lens of "other eyes." Historians' "other eyes" can thus be new sources or new approaches, as well as new questions to be raised.

The title of Marcel Proust's novel In Search of Lost Time (À la recherche $d u$ temps perdu) provides a good metaphor for the topic of this book, in which I want to discuss whether the time preceding the late introduction of Ottoman Turkish printing was lost or wasted in waiting for the first printer, if one can speak of a "waiting" at all. Reconsidering the issue in the light of recent scholarship on Ottoman history, on the one hand, and the history of the book, on the other, I thus propose to look at the topic with "other eyes."
\end{abstract}

1 "The only true voyage of discovery, the only fountain of Eternal Youth, would be not to visit strange lands but to possess other eyes," quoted after Marcel Proust, Remembrance of Things Past [In Search of Lost Time], vol. 5: The Captive, trans. C. K. Scott Moncrieff (London: Chatto \& Windus, 1929), 253. 
The first paradigm in which this topic was hitherto considered is the decline theory that was-until recently-deeply rooted in the scholarship of Ottoman state and society. Lately, however, this theory has been disputed. A new generation of scholars has suggested a revised view of the period after the late sixteenth century, which is considered to have been a time of slow but irreversible institutional and social transformation. ${ }^{2}$ The decline paradigm suggests a priori underdevelopment and inevitable failure in every initiative to introduce novelty. The lack of printing long after the heyday of the Ottoman state in the sixteenth century, as well as the allegedly disappointing start of Ottoman Turkish printing in the first half of the eighteenth century, were perfectly fitting within that paradigm. However, newly found documentary evidence about that enterprise makes it clear that the decline theory is nothing but a farfetched construct that could hardly account for all the facts in the alleged trend of decline. I have been fortunate enough to come across the probate inventory (tereke defteri) relating to the possessions of İbrahim Müteferrika (c. 1670-1747) the founder of the first Ottoman Turkish typography—preserved in the Mufti Archives of Istanbul. ${ }^{3}$ This source, dated 20 Rebiü'l-ahīr 1160/April 1, 1747, is thus far the most illuminating with regard to many hitherto unknown aspects of Müteferrika's personality and printing enterprise. ${ }^{4}$

Scholars dealing with history of the book admit that the introduction of printing with movable type in Europe provided a new alternative way of multiplying texts that was only a complementary and coexisting technology along with manuscript copying well until the eighteenth century. In different sociocultural contexts, printing showed different degrees of efficiency and replaced the manuscript tradition in an evolutionary rather than a revolutionary way. ${ }^{5}$

2 See the latest overview of the decline scholarship in: Dana Sajdi, "Decline, Its Discontents and Ottoman Cultural History: By Way of Introduction," in Ottoman Tulips, Ottoman Coffee. Leisure and Lifestyle in the Eighteenth Century, ed. Dana Sajdi (London and New York: I. B. Tauris \& Co, 2007), 1-40.

3 For more details about that archive, see Yvonne J. Seng, "The Şer'iye Sicilleri of the Istanbul Müftülüğü as a Source for the Study of Everyday Life," Turkish Studies Association Bulletin 15, no. 2 (1991): 307-25.

4 İstanbul Müftülüğü Şeriye Sicilleri (Istanbul): Kısmet-i Askeriye Mahkemesi, defter 98, fol. 39a-40b. See the facsimile and the transliteration of this inventory in modern Turkish orthography in: Orlin Sabev, İbrahim Müteferrika ya da İlk Osmanlı Matbaa Serüveni (17261746). Yeniden Değerlendirme, 4th ed. (Istanbul: Yeditepe Yayınevi, 2016), 370-82, 439-41.

5 See Robert A. Houston, Literacy in Early Modern Europe. Culture and Education 1500-1800 (London: Longman, 1988); Brian Richardson, Printing, Writers and Readers in Renaissance Italy (Cambridge: Cambridge University Press, 1999); Adrian Johns, The Nature of the Book. Print and Knowledge in the Making (Chicago: The University of Chicago Press, 1998); 
Having this in mind, one should be much more indulgent as far as the formation of Ottoman or Islamic print culture is concerned. Yet, we still have no clear definition of what print culture is in itself.

The new approaches and theories suggested by recent scholarship as well as the newly found documentary evidence provide a reasonable basis for raising new and hitherto almost neglected (despite their great importance) questions relating to Ottoman Turkish printing. One of the new questions would be reframing the old one "Have the Ottomans indeed been late in adopting printing technology?”: instead asking why Ottoman Turkish printing was introduced so late, one could ask why it was launched exactly in the first half of the eighteenth century, for instance.

My intention here is to review the existing answers to the old questions, as well as to raise new questions and suggest answers. I have no ambitions to suggest new answers to the old questions, while the answers to the new questions might seem old and well known. Rather, I will dwell on why some questions could be considered out of date and others currently important. Hence, the goal of this book is not to offer a comprehensive study of printing in the Ottoman Empire, or even of Ottoman Turkish/Muslim printing, ${ }^{6}$ but to draw scholarly attention to some still controversial issues and to suggest a personal view, which might well be also controversial or dissatisfying. However, it could at least-I am convinced - stimulate the conception of new far better theses. ${ }^{7}$

Assa Briggs and Peter Burke, A Social History of the Media: From Gutenberg to the Internet (Cambridge: Polity Press, 2003); David McKitterick, Print, Manuscript and the Search for Order, 1450-1830 (Cambridge: Cambridge University Press, 2003).

6 It is more or less done. See Sabev, İbrahim Müteferrika (first edited in Bulgarian in 2004 and Turkish in 2006).

7 I have already drawn attention to these controversial issues in some of my publications: Orlin Sabev, "Formation of Ottoman Print Culture (1726-1746): Some General Remarks," in New Europe College. Regional Program 2003-2004, 2004-2005, ed. Irina Vainovski-Mihai (Bucharest: New Europe College, 2007), 293-333; Orlin Sabev, "The First Ottoman Turkish Printing Enterprise: Success or Failure (A Reassessment)," in Ottoman Tulips, Ottoman Coffee: Leisure and Lifestyle in the Eighteenth Century, ed. Dana Sajdi (London: I. B. Tauris \& Co, 2007), 63-89; Orlin Sabev, "A Portrait of the Printer as a Young Man. The Transylvanian Past of the First Ottoman Printer," Colloquia Journal of Central European History 15 (2008): 30-43; Orlin Sabev, "Rich Men, Poor Men: Ottoman Printers and Booksellers Making Fortune or Seeking Survival (Eighteenth-Nineteenth Centuries)," Oriens 37 (2009): 177-90 (reprinted in The History of the Book in the Middle East, ed. Geoffrey Roper [London: Ashgate Publishing, 2013], 319-32); Orlin Sabev, "En attendant Godot. La formation d'une culture imprimée ottomane," Études balkaniques Recherches interdisciplinaires sur les mondes hellénique et balkanique Cahiers Pierre Belon 16 (2009): 219-37; Orlin Sabev, "A Virgin Deserving Paradise or a Whore Deserving Poison: Manuscript Tradition 
It seems appropriate to begin with a brief survey of the existing answers to the probably most disputed old issue: why the Ottomans were for so long reluctant to adopt the printing technology and thereby to facilitate the multiplication of their texts. The answers given by most Turkish scholars are usually tinged with the wish to defend their sense of national pride. For the late introduction of printing by the Ottomans is not only an issue for scholarship; it is equally an issue that shakes the Turkish national consciousness because it strengthens the existing sense of underdevelopment. This is why one can find the issue to be discussed even in the major Turkish newspapers. My attention to this issue was first attracted by such a discussion in the Turkish daily Milliyet under the headline "Why was Printing Press Introduced to the Ottomans Too Late?" The sense of backwardness makes modern Turkish scholars and intellectuals defend their national pride by searching for not necessarily reasonable but always apologetic explanations for that question. Only recently have some Turkish scholars, like Hidayet Nuhoğlu and Hüseyin Gazi Topdemir, insisted that such an approach is not needed anymore. ${ }^{9}$ The reasons for the late introduction of Ottoman Turkish printing as discussed in the existing scholarship could be summarized as follows:

- Psychological and ideological reasons: the Ottomans were reluctant to adopt printing technology with movable type since it was an invention of Christian Europe; if they adopted this invention they would possibly admit the Christians' supremacy over them; by refusing to

and Printed Books in Ottoman Turkish Society," in Friars, Nobles and Burghers-Sermons, Images and Prints. Studies of Culture and Society in Early-Modern Europe, In Memoriam István György Tóth, ed. Jaroslav Miller and László Kontler (Budapest: Central European University Press, 2010), 389-409 (reprinted in The History of the Book in the Middle East, ed. Geoffrey Roper [London: Ashgate Publishing, 2013], 143-64); Orlin Sabev, "In Search of Lost Time: How 'Late' was the Introduction of Ottoman Turkish Printing?, in Europa und die Türkei im 18. Jahrhundert/Europe and Turkey in the Eighteenth Century, ed. Barbara SchmidtHaberkamp (Göttingen: Bonn University Press by V\&R Unipress, 2011), 447-56; Orlin Sabev, "Waiting for Godot: the Formation of Ottoman Print Culture," in Historical Aspects of Printing and Publishing in Languages of the Middle East. Papers from the Third Symposium on the History of Printing and Publishing in the Languages and Countries of the Middle East, University of Leipzig, September 2008, ed. Geoffrey Roper (Leiden: Brill, 2014), 101-20; Orlin Sabev, "Portrait and Self-Portrait: İbrahim Müteferrika's Mind Games," Osmanl Araştırmalar/The Journal of Ottoman Studies 44 (2014): 99-121.

8 Milliyet 20 (August 9, 2001), 2.

9 See Hidayet Nuhoğlu, "Müteferrika Matbaası ve Bazı Mulâhazalar," in Osmanlı, ed. Güler Eren, vol. 7 (Ankara: Yeni Türkiye, 1999), 221-29; Hüseyin Gazi Topdemir, İbrahim Müteferrika ve Türk Matbaacılığı (Ankara: T. C. Kültür Bakanlı̆̆ı, 2002), 27-39. 
adopt it the Ottomans tried to preserve their cultural identity; the superciliousness of the Ottomans as rulers made them abstain from adopting a technology that was used by their Jewish, Armenian, and Greek subjects. ${ }^{10}$ The Muslim religious scholars and functionaries were allegedly against such a Christian invention, condemning it as a "blasphemy." 11 In other words, the defensive behavior restricted the Ottomans, or, in a broader sense, the Islamic world in the cramped framework of tradition. ${ }^{12}$ The Ottomans were ready to adopt printing only during the so-called Tulip Age (1718-30), when such an adoption was facilitated by a process which is believed to have been similar to the European Renaissance. ${ }^{13}$

- Socioeconomic reasons: the Ottomans were concerned about the livelihood of the numerous manuscript copyists; introduction of printing could have shaken the established social order. ${ }^{14}$

- Sociocultural reasons: since the manuscript tradition was quite developed, it satisfied the demands of the reading public. ${ }^{15}$

10 Selim Nüzhet Gerçek, Türk Matbaacıllğı, I. Müteferrika Matbaası (Istanbul: Maarif Vekâleti, 1939), 33-34; İsmet Binark, “Türkiye’ye Matbaanın Geç Girişinin Sebepleri Üzerine," Türk Kültürü 65 (1968): 295-304; İsmet Binark, "Matbaanın Türkiye’ye Geç Girişinin Sebepleri," in Basım ve Yayıncllı̆ımızın 250. Yilı Bilimsel Toplantısı, 10-11 Aralık 1979, Ankara, Bildiriler (Ankara: Türk Kütüphaneciler Derneği, 1980), 139-73; İsmet Binark, “Türkiye'ye Matbaanın Geç Girişinin İçtimaî-Ruhî Sebepleri," in VIII. Türk Tarih Kongresi, Ankara 11-15 Ekim 1976, Kongreye Sunulan Bildiriler, vol. 2 (Ankara: Türk Tarih Kurumu Yayınları, 1981), 1299-1319; İsmet Binark, “Matbaanın Türkiye’ye Geç Girişinin Sebepleri,” Yeni Türkiye 12 (1996): 1599-1616.

11 Ahmet H. Rafikov, Ocherki istorii knigopechataniia v Turtsii (Leningrad: Nauka, 1973), 15-29; A. D. Jeltyakov, Türkiyénin Sosyo-Politik ve Kültürel Hayatında Basın (1729-1908 Yilları) (Ankara: Basın Yayın ve Turizm Genel Müdürlüğü, 1979), 21; Orhan Koloğlu, Basımevi ve Basının Gecikme Sebepleri ve Sonuçları (Istanbul: İstanbul Gazeteciler Cemiyeti, 1987), 8-55.

12 Yusuf Kaplan, “Osmanlılarda Matbaa: Bir Medeniyet Krizi Sorunu," in Osmanl, ed. Güler Eren, vol. 7 (Ankara: Yeni Türkiye, 1999), 230-37.

13 Topdemir, İbrahim Müteferrika, 27-39.

14 Binark, "Türkiye’ye Matbaanın Geç Girişinin Sebepleri Üzerine”; Binark, "Matbaanın Türkiye’ye Geç Girişinin Sebepleri”; Binark, “Türkiye’ye Matbaanın Geç Girişinin İçtimâ̂Ruhî Sebepleri”; Koloğlu, Basımevi ve Basının Gecikme Sebepleri ve Sonuçlarl, 8-55; Wahid Gdoura, Le début de l'imprimerie arabe à Istanbul et en Syrie: Évolution de l'environnement culturel (1706-1787) (Tunis: Institut Superieur de Documentation, 1985), 83-122.

15 Nuhoğlu, "Müteferrika Matbaası ve Bazı Mulâhazalar," 225-26; Mustafa Armağan, "Prof. Dr. İlber Ortaylı ile Konuşma: Bir Kabuk Değiştirme Dönemi," in İstanbul Armağanı. 4: Lâle Devri, ed. Mustafa Armağan (Istanbul: İstanbul Büyükşehir Belediyesi Kültür İşleri Daire Başkanlığı Yayınları, 2000), 61-73; Christoph K. Neumann, “Üç Tarz-ı Mütalaa. Yeniçağ 
- Technical and aesthetic reasons: adjustment of printing with movable type to the cursive Arabic script was far more problematic as compared to non-cursive alphabets like Latin, Greek, Hebrew, Armenian, and Cyrillic. For this reason, the invention of the printing press did not necessarily offer easier, faster, and cheaper multiplication of texts. Aesthetically, printed texts in Arabic script were inferior to the elegant manuscripts. ${ }^{16}$

- $\quad$ Financial reasons: printing required considerable initial investments as compared to manuscript copying. ${ }^{17}$

Each of the abovementioned explanations can be considered more or less reasonable, and a variety of combinations of them may serve as a general explanation. However, what is troublesome about such an approach is that scholars were/are trying to explain something which seems problematic in their own "eyes" but not problematized or dramatized by the Ottomans themselves. In other words, there is no evidence that the Ottomans experienced a dilemma about whether to print or not to print. If so, why do modern scholars dramatize so much the lack of Ottoman Turkish printing until well into the eighteenth century? ${ }^{18}$

It is true that the seventeenth-century Ottoman intellectual Mustafa bin Abdullah, known mostly by the names Katib Çelebi and Haji Khalifa/ Hacı Halife (1609-57), who, among others, considered printing somewhat a "strange" art-a consideration discussed at length in chapter 1 -complained that he was able to put in his famous geographical work Cihānnümā (Mirror of World) only a few maps since the art of printing was not in common use in his country. ${ }^{19}$ Therefore-as he admits - it was difficult to draw even a page

Osmanlı Dünyası'nda Kitap Yazmak ve Okumak," Tarih ve Toplum. Yeni Yaklaşımlar 1 (2005): 51-76.

16 Koloğlu, Basımevi ve Basının Gecikme Sebepleri ve Sonuçları, 8-55; Francis Robinson, "Technology and Religious Change: Islam and the Impact of Print," Modern Asian Studies 27/I (1993): 229-51.

17 Gdoura, Le début de l'imprimerie arabe à Istanbul et en Syrie, 83-122.

18 Christoph K. Neumann claims that the late introduction of Ottoman Turkish printing and the lack of interest in printing in the Ottoman Turkish society up to the eighteenth century should be considered a manifestation of a certain cultural mode rather than a disadvantage as traditional scholarship tends to think. See Neumann, "Üç Tarz-ı Mütalaa. Yeniçağ Osmanlı Dünyası'nda Kitap Yazmak ve Okumak," 57.

19 It was true, in fact, only for the Turkish-speaking segment of Ottoman society since Jewish, Armenian, and Greek printing presses were already operating in Katib Çelebi’s time. 
(bu diyārda basma istimāl olunmāmak ile bir sahifesini bile resm emr-i asirdir). ${ }^{20}$ However, as Orhan Koloğlu points out, Katib Çelebi did not recommend to his compatriots the adoption of printing. ${ }^{21}$ Katib Çelebi's last work, Balance of Truth (Mizānü'l-hakk, 1656), which contains a number of essays on controversial issues related to Islamic doctrine and practice, is completely silent about printing, apparently because it was not yet a part of the Ottoman agenda. The author (and obviously his contemporaries) was more concerned about the ignorance of the rational sciences or preoccupied with the issue of whether to drink or not to drink coffee, and more importantly with the most controversial issue of the Ottoman seventeenth century, the Sufi views and practices that had been contested by the influential Kadizadeli movement (1630s-80s). ${ }^{22}$ In other words, in the Ottoman seventeenth century printing was an issue which did not receive any serious attention. One possible reason for this could be the simple fact that for the Ottomans, printing did not seem a good enough alternative to manuscript copying. However, Katib Çelebi's explicit complaint about the lack of printing facilities - particularly for maps — is an implicit indication that some pre-eighteenth-century Ottoman intellectuals felt the need for printing. One must recall here that İbrahim Müteferrika's initial attempts at printing were — maybe not for nothing - related to cartography.

Given this, should we consider the time before the eighteenth century, when Ottoman Turkish printing was at last introduced, "lost" or "wasted"? A lot of western travelers were curious about the reasons for the lack of Ottoman Turkish printing, but the Ottomans themselves seemed to be quite undisturbed by any feeling of backwardness or of being old-fashioned in comparison with other societies. Such a feeling would begin to arise only in the eighteenth century and gain importance throughout the nineteenth century.

As stated above, contrary to the question of why the Ottomans did not print their books as early as their European counterparts, we might consider

20 Kitāb-ı Cihānnümāa li-Kātib Çelebi (Constantinople: Dārü't-tıbāati'l-ma'mūre, 1145/1732), 55; Gerçek, Türk Matbaacıllğı, 80; Hamit S. Selen, “Cihannümā,” in Kâtip Çelebi Hayatı ve Eserleri Hakkinda İncelemeler (Ankara: Türk Tarih Kurumu Yayınları, 1991), 131; Osman Ersoy, Türkiye'ye Matbaanın Girişi ve İlk Basılan Eserler (Ankara: A. Ü. Dil ve Tarih-Coğrafya Fakültesi, 1959), 30 (the author quotes Selen's publication but presents incorrectly Katib Çelebi's words in claiming that printing has been forbidden).

21 Koloğlu, Basımevi ve Basının Gecikme Sebepleri ve Sonuçları, 30.

22 See Geoffrey L. Lewis, ed. and trans., The Balance of Truth by Kātib Çelebi (London: George Allen and Unwin Ltd., 1957); Madeline C. Zilfi, "The Kadizadelis: Discordant Revivalism in Seventeeth-Century Istanbul," Journal of Near Eastern Studies 45, no. 4 (1986): 251-69. 
the question of why Ottoman Turkish printing was introduced in the first half of the eighteenth century - at exactly that time in history.

Hüseyin Gazi Topdemir points out that the introduction of Ottoman Turkish printing was completely due to the personal efforts of the founder of the first Ottoman Turkish printing house, İbrahim Müteferrika, and therefore Topdemir holds the opinion that the question of whether Ottoman Turkish printing was late is meaningless. ${ }^{23}$ Indeed, the personal factor is quite important, because every invention has its inventor, and every adoption of an invention has its agent. However, it is of equal importance whether such an agent enjoys a favorable milieu and sufficient support in his innovative efforts. The existence or lack of the latter would make these efforts achieve success or face failure.

With regard to this, one may recall Müteferrika's statement about printing presented to the Ottoman governors, in which he stated that many previous efforts for introduction of printing had failed. However, there is still no particular historical evidence for such efforts. Some historical circumstances could potentially provide opportunities for the introduction of Ottoman Turkish printing even in the late fifteenth century. For instance, Sultan Mehmed II the Conqueror (b. 1432, r. 1444-46 and 1451-81) invited Leonardo da Vinci (1452-1519) to serve as a court painter in the Ottoman capital. Leonardo refused the offer, having only recently started working as a military engineer for the Sforza court in Milan. However, when Milan was captured by the armies of France in 1499 and Duke Sforza incarcerated, Leonardo abandoned the city and wrote the then Ottoman sultan Bayezid II (b. 1447; r. 1481-1512) a letter, offering his service as a military engineer with the intention to build a single-arch bridge over the Golden Horn. It seems that the new sultan was not impressed or interested at all and Leonardo was not invited. ${ }^{24}$ Since Leonardo designed a printing press in c. $1480-82,{ }^{25}$ one may presume that he could possibly have introduced the art of printing to the Muslims if he had accepted the first invitation or had been invited a second time to the Ottoman court. Thus, in Leonardo's case, historical circumstances were unfavorable.

23 Topdemir, İbrahim Müteferrika, 27-39.

24 See Franz Babinger, "Vier Bauvorschläge Lionardo da Vinci's an Sultan Bajezid II. (1502/3)," in Nachrichten der Akademie der Wissenschaften in Göttingen, I. Philologisch-Historische Klasse 1 (Göttingen: Vandenhoeck \& Ruprecht, 1952); Bülent Atalay, "Leonardo: A Man for All Seasons," in The Genius of Leonardo. Exhibition Catalogue (Istanbul: Rahmi M. Koç Muzeum, 2006), 31.

25 See The Genius of Leonardo. Exhibition Catalogue (Istanbul: Rahmi M. Koç Muzeum, 2006), 66-67. 
It is true also that the first Ottoman Turkish printing press was established through the personal effort of İbrahim Müteferrika, and not through a state initiative. Sinan Kuneralp describes Müteferrika as one of those "unusual" persons - or "out of the ordinary" ("personnages hors du commun") — that appear in Ottoman history from time to time. ${ }^{26}$ Chapter 2 is devoted to this "unusual" personality. Müteferrika was of Hungarian and Protestant (allegedly Unitarian) origin and became an Ottoman subject and convert to Islam when he was between the age of eighteen and twenty. He was probably already skilled at the art of printing while still in his hometown of Kolozsvár (today's ClujNapoca), Transylvania (today in Romania). He was at least a confident bearer of print culture, eager enough to undertake a risky enterprise such as the establishment of the first Ottoman Turkish printing press. On the other hand, in his service at the Ottoman court he created good relationships with the most influential Ottoman statesmen, making the implementation of his enterprise easier. Yet a number of non-Muslim printers existed, who could have run a press to print books for the Muslim reading public. But it seems that the Ottoman ruling class, obliged to be Muslim by birth or conversion, would never allow a non-Muslim to print books for Muslims. Hence, someone Muslim who was skillful at the art of printing was needed to launch such an enterprise.

The time was of vital importance not for the Ottomans themselves but for Müteferrika himself, because he appeared in quite a favorable historical moment, the period of Nevşehirli Damad İbrahim Pasha's (b. 1666-d. 1730) service as grand vizier, the so-called Tulip Age (1718-30). ${ }^{27}$ The adoption of printing technology was closely connected with the sociocultural developments during

26 Sinan Kuneralp, "Les débuts de l'imprimerie à Istanbul au XVIII ${ }^{\mathrm{e}}$ siècle," in Turquie: Livres d'hier, livres d'aujourd'hui, ed. Paul Dumont (Strasbourg: Centre de recherche sur la Civilisation ottomane et le domaine turc contemporain Université des Sciences HumainesLes Éditions Isis, 1992), 3.

27 For the historiographical construction of the Tulip Age see Ahmet Ö. Evin, "The Tulip Age and the Definitions of 'Westernization,"' in Social and Economic History of Turkey (1071-1920), Papers Presented to the First International Congress on the Social and Economic History of Turkey (Ankara: Hacettepe University, July 11-13, 1977), ed. Halil İnalcık and Osman Okyar (Ankara: Meteksan, 1980), 131-45; Fatma Müge Göçek, East Encounters West: France and the Ottoman Empire in the Eighteenth Century (New York: Oxford University Press, 1987), 72-81; Can Erimtan, Ottomans Looking West? The Origins of the Tulip Age and its Development in Modern Turkey (London: I. B. Tauris, 2008); Selim Karahasanoğlu, “İstanbul’un Lale Devri Mi? Tarih ve Tarih Yazımı," in Tarih İ̧inde İstanbul Uluslararası Sempozyumu/Istanbul throughout History International Symposium 14-17 Aralik/December 2010. Bildiriler, ed. Davut Hut, Zekeriya Kurşun, and Ahmet Kavas (Istanbul: Mtt İletişim ve Reklam Hizmetleri, 2011), 427-63. Selim Karahasanoğlu, A Tulip Age Legend: Consumer Behavior and Material Culture in the Ottoman Empire (1718-1730) (PhD diss., Binghamton University, State University of New York, 2009). 
the Tulip Age, ${ }^{28}$ and that is why the contextualization of the first Ottoman Turkish printing press within the framework of these developments is unavoidable. The major trend that started during that age was the so-called westernization of the Ottoman Empire, which was to a great extent sparked by the first Ottoman long-term embassy to France. The almost one-year-long embassy that took place in 1720-21 provoked among the Ottoman elite a remarkable interest in western culture, luxurious lifestyle, architectural styles such as Rococo and Baroque, and findings in the field of geography, astronomy, biology, medicine, as well as printing. The western influence, however, did not replace immediately and completely the traditional Ottoman culture. It was adapted rather than merely adopted, thus creating, in Fatma Müge Göçek's words, a "cultural dichotomy" 29 or, in Rifaat Ali Abou-el-Haj's expression, a "cultural symbiosis." ${ }^{30}$ In such an atmosphere, far more opened to the western counterpart as compared with previous times, the Ottoman elite, or at least a part of it, inclining to make use of selected western achievements, supported the establishment of a typography to print books for the Turkish-speaking Muslim reading public.

The printing enterprise happened to be just one of the "eccentric" novelties the then Ottomans felt comfortable with. In fact, printing might have not been as obsessive as the cultivation of tulips, a flower that became the object of extreme adoration during that period, ${ }^{31}$ and the erection of new residences by adopting or adapting European or Iranian architectural styles, ${ }^{32}$ but at least it enjoyed a favorable environment at a time when-it seems-everything was possible and allowed. Sexual pleasure and prostitution were gaining more

28 See Wilhelm Heinz, "Die Kultur der Tulpenzeit des Osmanischen Reiches," Wiener Zeitschrift für die Kunde des Morgenlandes 61 (1967): 62-116.

29 Göçek, East Encounters West, 81.

30 Rifaat Ali Abou-el-Haj, Formation of the Modern State. The Ottoman Empire Sixteenth to Eighteenth Centuries (Albany: State University of New York Press, 1991), 67.

31 See Münir Aktepe, “Damad İbrahim Paşa Devrinde Lâle," İstanbul Üniversitesi Edebiyat Fakültesi Tarih Dergisi 4, no. 7 (1952): 85-126.

32 See Ali Uzay Peker, "Western Influences on the Ottoman Empire and Occidentalism in the Architecture of Istanbul," Eighteenth-Century Life 26, no. 3 (2002): 139-63; Shirine Hamadeh, "Ottoman Expressions of Early Modernity and the 'Inevitable' Question of Westernization," Journal of the Society of Architectural Historians 63, no. 1 (2004): 32-51; Shirine Hamadeh, "Westernization, Decadence, and the Turkish Baroque: Modern Constructions of the Eighteenth Century," Muqarnas 24 (2007), 185-197; Shirine Hamadeh, The City's Pleasures: Istanbul in the Eighteenth Century (Seattle: University of Washington Press, 2007); Can Erimtan, "The Perception of Saadabad: The 'Tulip Age' and Ottoman-Safavid Rivalry," in Ottoman Tulips, Ottoman Coffee. Leisure and Lifestyle in the Eighteenth Century, ed. Dana Sajdi (London: I. B. Tauris \& Co, 2007), 41-62. 
socially visible dimensions, ${ }^{33}$ and even pornographic miniature images were being depicted far more boldly than ever before. ${ }^{34}$

The Tulip Age terminated in quite a dramatic way, showing how violence and peace, destructivity and creativity could exist simultaneously in history at one and the same place. On September 28, 1730, the Albanian Patrona Halil (d. 1730), a dealer in ready-made goods, sparked the so-called Patrona Revolt that involved the Istanbul citizens, traders, and artisans, along with the military, and led to Damad İbrahim Pasha's execution and Sultan Ahmed III's (b. 1673-d. 1736, r. 1703-30) resignation from the throne. ${ }^{35}$ A contemporary of this revolt, Abdi Efendi, ${ }^{36}$ relates vividly that on the very first day of the revolt, while the insurgents were angrily rushing into the Istanbul streets, on the Asian shore of the Bosphorus the grand vizier and the other state officials were entertaining themselves at the military campus in Üsküdar, and the grand vizier's deputy (kaymakam) was innocently planting tulips in his garden. ${ }^{37}$

Despite its dramatic end, the Tulip Age saw the first Ottoman efforts at modernization by following western patterns and adopting European aesthetical norms and technological achievements, with the printing press being the most striking technological break from the traditional Ottoman culture. In 1727, Ahmed III authorized İbrahim Müteferrika and Said Çelebi (d. 1761) to run a printing house, which was the first to print books with Arabic script in the Ottoman Empire. Said Çelebi joined the diplomatic mission to France in 1720-21, headed by his father Yirmisekiz Mehmed Çelebi (d. 1732), and provided financial and organizational support to Müteferrika in the very

33 See Fariba Zarinebaf, Crime and Punishment in Istanbul, 1700-1800 (Berkeley: University of California Press, 2010), 86-111; Orlin Sabev, "Ahlâkın Arka Sokakları: 18. Yüzyıl Osmanlı İstanbulu'nda Fuhuş ve Ceza," in Osmanlı İstanbulu IV: IV. Uluslararası Osmanlı İstanbulu Bildirileri 20-22 Mayıs 2016, İstanbul 29 Mayıs Üniversitesi, ed. Feridun M. Emecen, Ali Akyıldız, and Emrah Safa Gürkan (Istanbul: 29 Mayıs Üniversitesi Yayınları, 2016), 621-42.

34 See Tülay Artan and İrvin Cemil Schick, "Ottomanizing Pornotopia: Changing Visual Codes in Eighteenth-century Ottoman Erotic Miniatures," in Eros and Sexuality in Islamic Art, ed. Francesca Leoni and Mika Natif (Farnham: Ashgate Publishing, 2013), 157-207.

35 For more details about the Patrona Revolt, see Münir Aktepe, Patrona İsyanı (1730) (Istanbul: İ. Ü. Edebiyat Fakültesi, 1958); Robert W. Olson, "The Esnaf and the Patrona Halil Rebellion of 1730: A Realignment in Ottoman Politics?" Journal of the Economic and Social History of the Orient 17, no. 3 (1974): 329-44.

36 See Franz Babinger, "Abdī Efendi," in The Encyclopaedia of Islam, new ed., vol. 1, ed. H. A. R. Gibb, J. H. Kramers, E. Lévi-Provençal, and J. Schacht (Leiden: Brill, 1986), 97.

37 Faik R. Unat, ed., Abdî Tarihi (1730 Patrona İhtilâli Hakkında Bir Eser) (Ankara: Türk Tarih Kurumu Yayınları, 1943), 29-30. 
beginning of his undertaking. Thus, Müteferrika's personal effort seems to be as important as the state support in introducing the art of printing.

To summarize, one could suggest the following answer to the question of why Ottoman Turkish printing appeared exactly in the first half of the eighteenth century: there seems to have been a favorable coexistence and combination of important factors, such as the appearance of a capable and enterprising person like Müteferrika, a Muslim convert, and the specific demand for certain texts existing among the Ottoman elite, as well as the willingness of the rulers to support such an enterprise financially and institutionally.

Müteferrika's appearance on the stage of Ottoman history in the first half of the eighteenth century seems to be good fortune, somewhat resembling Samuel Beckett's Godot. As Beckett's play Waiting for Godot (En attendant Godot) implies, chance is the underlying factor behind human existence and, as a direct result, time has no meaning. ${ }^{38}$ However, the similarity to Waiting for Godot is confined only to the concept of time. Beckett's characters Vladimir and Estragon are constantly waiting for Godot but he never appears, while the Ottomans were not seemingly waiting for their first printer faithfully and impatiently when Müteferrika appeared all of a sudden in the first half of the eighteenth century.

Chapter 3 deals with the operation of the Müteferrika press between 1726 and 1746 and analizes its output in the light of the traditional Ottoman/Muslim concept of learning and knowledge diffusion as well as of Müteferrika's personal educational/religious background and publishing policy. Müteferrika printed sixteen editions in twenty-two volumes, including eighteen titles. One of them, a manual of the Turkish language, was intended not for Ottoman/Muslim readers but rather the Francophone reading public. Of the remaining seventeen titles, two were dictionaries (Arabic-Turkish and Persian-Turkish, respectively), ten dealt with history, two others combined historical and geographical accounts, one was completely a geographical work, one was on physics, and one was on political and military issues. The books Müteferrika offered to the public (actually, a rather limited segment of that public) created their own demand because they were rare and not easily available, and because of the scarcity of relatively current information. They also challenged the traditional Ottoman or Islamic concept of knowledge diffusion, which gave privilege to religious literacy. The commercial balance

38 See the comments at the following website: http://www.freeessays.cc/db/philosophy/ index.shtml (retrieved on March 25, 2005). 
of Müteferrika's enterprise, as discussed in chapter 4, while not disastrous, was not staggeringly successful either. However, sales figures clearly show that his business was far from the fiasco presented in scholarly and literary sources. By the end of his life he sold about 70 percent of the books he printed, even though their topics were far from being the most popular, competitive, or profitable in the book market.

Müteferrika's efforts in printing seem a fruitful combination of personal enthusiasm and a response to an increasing demand of the Ottoman elite for books on certain topics. As I have tried to demonstrate in chapter 5, when his prints became artifacts in a world dominated by the manuscript tradition, they provided an alternative way of multiplying texts, shortening the time and widening the space of knowledge and information diffusion. Yet they set a precedent that made the next generations accept the idea of printing and become its active promoters. ${ }^{39}$

39 See Geoffrey Roper, "The Printing Press and Change in the Arab World," in Agent of Change: Print Culture Studies after Elizabeth A. Eisenstein, ed. Sabrina Baron, Eric N. Lindquist, and Eleanor F. Shevlin (Amherst: University of Massachusetts Press, 2007), 250-52. 
